\title{
SOB A ÉGIDE DA REVOLTA - O CONDE DE MONTE CRISTO E A CRÍTICA DE ANTONIO CANDIDO
}

\section{UNDER THE AEGIS OF THE REVOLT - THE COUNT OF MONTE CRISTO AND THE CRITIC OF ANTONIO CANDIDO}

\author{
Mona Lisa Bezerra Teixeira ${ }^{1}$ \\ Doutorado - Universidade de São Paulo
}

\begin{abstract}
RESUMO
Antonio Candido em seu ensaio "Monte Cristo ou da vingança", publicado em 1952, analisa os principais aspectos que caracterizam um herói romântico e utiliza, como figura central para sua reflexão, Edmond Dantès, o protagonista de O conde de Monte Cristo, de Alexandre Dumas. Mais adiante, publicaria novamente esse texto com alguns acréscimos, no seu livro Tese e antítese, em 1964, dando o nome de "Da Vingança". Sem esquecer os grandes nomes da literatura europeia como Byron, Stendhal e Balzac, o crítico observa como a essência da narrativa é, por princípio, burguesa, e como a transformação de Dantès está ligada ao individualismo, traço marcante do movimento romântico, que resultará em contradições e vivências problemáticas desse personagem, um dos mais emblemáticos do escritor francês e da história da literatura ocidental.
\end{abstract}

PALAVRAS-CHAVE: Antonio Candido; Conde de Monte Cristo; Vingança; Movimento Romântico.

\begin{abstract}
Antonio Candido in his essay "Monte Cristo or on vengeance", published in 1952, analyzes the main aspects that characterize a romantic hero and uses as central figure for his reflection Edmond Dantès, the protagonist of The Count of Monte Cristo by Alexandre Dumas. Later, he would publish this text again with a few additions, in his book Thesis and antithesis, in 1964, giving the name of "On vengeance". Without forgetting the great names of European literature such as Byron, Stendhal and Balzac, the critic observes how the essence of the narrative is, in principle, bourgeois, and how the transformation of Dantès is linked to individualism, a striking feature of the romantic movement, which will result in contradictions and problematic experiences of this character, one of the most emblematic of the French writer and of the history of Western literature.
\end{abstract}

KEYWORDS: Antonio Candido; Count of Monte Cristo; Vengeance; Romantic Movement.

\section{INTRODUÇÃO}

Para comentar os principais aspectos do protagonista do romance de Alexandre Dumas, Edmond Dantès, Antonio Candido (1971) inicia seu estudo "Da vingança" ${ }^{2}$ destacando uma das características mais marcantes do movimento romântico: a ênfase na natureza, em conjunto com as ações da personagem. Tal aspecto demarca com veemência um dos momentos cruciais da

\footnotetext{
1 Doutora em Teoria da Literatura e Literatura Comparada pela Universidade de São Paulo. E-mail: mlbteixeira.mt@gmail.com

${ }^{2} \mathrm{O}$ autor indica em Tese e antítese (1971) que o ensaio teve versão publicada anteriormente no "Caderno de Cultura n. 10 do Serviço de Divulgação do Ministério da Educação, sob o título: Monte Cristo ou da vingança".
} 
narrativa, quando o ex-prisioneiro encontra, graças às orientações do falecido abade Faria, amigo e companheiro de prisão, o tesouro na ilha de Monte Cristo, que irá modificar a trajetória injustiçada de sua vida. O crítico observa que o autor destaca, no momento em que Dantès está em Monte Cristo, dois símbolos para a imaginação humana: a montanha, que representa as alturas, o mundo visto acima da perspectiva convencional, próximo aos anseios de poder e justiça da personagem, e a caverna, onde estão os recursos materiais que darão legitimidade e influência para alcançar seus objetivos. E, para reforçar seu argumento, tece considerações sobre escritores como Goethe, Stendhal, Vitor Hugo e Castro Alves, que, em suas obras, exploraram esteticamente os recantos obscuros da natureza e dos espaços físicos ocupados pelos homens, em contraponto com paisagens bucólicas e arquitetônicas nas alturas.

É interessante lembrar do encantamento que o próprio Alexandre Dumas teve ao ver a ilha, que seria a grande inspiração para o seu romance, e a forte impressão que a altura desta lhe causou. Em seu texto 'O estado civil de Monte Cristo", primeiramente chamado de "Uma palavra a respeito de O Conde de Monte Cristo", ele descreve que, em um período de férias, por volta de 1842, acompanhando um sobrinho de Napoleão Bonaparte ${ }^{3}$ acabou chegando até à ilha, mas não pôde desembarcar porque o território estava sob contumacia (quarentena).

À medida que avançávamos, Monte Cristo parecia sair do seio do mar e crescer como o gigante Adamastor. Nunca vi manto de anil mais belo do que aquele lançado sobre os seus ombros pelo sol nascente. (2008, p. 19).

Como bem observa Antonio Candido, no espaço físico da ilha, Edmond vai ultrapassando os obstáculos criados pela natureza até chegar à fortuna. Mas essa luta começa na verdade desde o momento de sua fuga do Castelo de If, quando é jogado ao mar ocupando na mortalha o lugar do falecido abade Faria. Depois de muito nadar, alcança uma porção de terra, enfrenta a fúria de uma tempestade e, após ser resgatado por contrabandistas, vai adquirir uma nova identidade, ao ser chamado de "Maltês" pelos novos companheiros. Precisa se manter sob esse primeiro disfarce e permanece com seus salvadores até o momento propício para a sua transformação em conde, e, a partir da riqueza vinda do tesouro oferecido pelo bondoso amigo falecido na prisão, terá também outras identidades para a realização de sua vingança contra os homens que o fizeram ficar preso injustamente durante 14 anos. Esse aspecto é um dos pontos fortes da narrativa de Alexandre Dumas, que dá várias faces ao personagem, pois ele será também "Simbad, o marujo", o representante inglês, sem nome, da "Casa Thomson \& French", o "abade Busoni" e o "lorde Wilmore".

Esse jogo de múltiplas identidades do protagonista não é analisado em minúcia por Antonio Candido, mas é um aspecto muito relevante para a dinamização da narrativa e fundamental para o plano de vingança, pois possibilita um fluxo de deslocamento diante das várias camadas da sociedade, que são frequentadas por Dantès, e reforça o que o crítico aponta com relação a importantes aspectos relacionados ao tema da vingança e ao movimento romântico, como a composição literária, a investigação psicológica, a análise sociológica e a visão de mundo:

Mas embora corresponda ao movimento próprio da estética romântica, é sobretudo às concepções românticas de homem e de sociedade que a vingança se presta como tema. O personagem romântico - dramático, desmedido, sangrento - encontrava nela a

\footnotetext{
${ }^{3}$ Esse sobrinho era Napoléon-Joseph-Charles-Paul Bonaparte (1822-1891), filho de Jerônimo Bonaparte, o irmão mais novo de Napoleão Bonaparte. Diante das dificuldades de desembarque, Dumas pede para contornarem a ilha para um reconhecimento geográfico de seu entorno, e quando lhe perguntam qual seria o objetivo de tal tarefa, responde: " - Para batizar com o nome da ilha de Monte Cristo algum romance que escreverei mais tarde." (DUMAS, 2008, p. 19).
} 
atmosfera da contradição e da surpresa, em que banha a sua psicologia. (CANDIDO, 1971, p. 16).

\section{Montanhas e subterrâneos}

Como ainda observa o crítico, serão as forças vindas do mundo subterrâneo que sustentarão os planos de Edmond, algo que pode ser aproximado da própria consciência do personagem, que, muitas vezes durante a história, terá que ocultar suas intenções e desejos para concretizar o seu plano de vingança. Em sua solidão, condição essencial para caracterizar um herói romântico, como lembra Antonio Candido, o personagem contempla o mar, que é também o mundo, e a partir daí começa a superar os obstáculos com a força provinda do que não está à vista, seja na perspectiva do tesouro enterrado, seja com relação aos sentimentos que ficarão encobertos diante dos outros homens. Assim, em muitos momentos durante a narrativa, a perspectiva da personagem se apresenta entre as alturas e as profundezas.

Em sua trajetória, há várias situações que reforçam essas manifestações: como na já citada fuga dentro da mortalha do abade Faria quando jogado ao mar das alturas do Castelo de If, na contemplação da paisagem pelos cumes da ilha de Monte Cristo, na aquisição de seu iate em Palermo, na posição ocupada da sacada do Palácio Ruspoli em Roma, onde observa tanto a alegria do carnaval quanto a crueldade das execuções em praça pública, na posse de cavalos e carruagens, nos camarotes luxuosos dos teatros, e, acima de tudo, no forte prestígio obtido através do dinheiro, que lhe dá acesso ao topo da sociedade. Mas, com uma presença tão significativa quanto a altura, está o movimento para baixo: na própria cela de If, na sua condição de contrabandista, na caverna do tesouro em Monte Cristo, na estalagem da Ponte do Gard, na presença das catacumbas em Roma, na história do bebê enterrado em Auteuil, na casa escura do senhor de Villefort, na condição aflitiva do senhor de Noirtier - muito doente e impossibilitado de se comunicar com clareza, quando somente ele é que seria capaz de desmascarar o próprio filho, Villefort.

\section{O indivíduo}

Em O conde de Monte Cristo, a narrativa é fundamentada na história de um indivíduo, que tem como objetivo principal aniquilar a reputação dos seus algozes. Dantès quer fazer justiça devido aos anos de aprisionamento, à morte por inanição de seu pai, à perda da mulher amada, Mercedes, e ao rompimento de sua trajetória profissional, promissora até o momento em que os invejosos funestos mudaram seu destino. A história da vingança, que revela um aspecto essencialmente individual, é um traço marcante do movimento romântico, que resultará em contradições e em uma vivência problemática do personagem. E é esse um dos principais atrativos da obra: as atitudes inesperadas de Dantès, sua frieza e violência, e mesmo a sua postura arrogante como novo milionário após a conquista do tesouro, em muitos momentos supera, propositadamente, a desfaçatez dos outros personagens endinheirados.

Mas essa história individual vai comportar outras histórias, que envolvem uma gama de personagens muito bem articulados, com o início da narrativa estruturada no período do retorno de Napoleão Bonaparte de seu exílio na ilha de Elba. Será esse episódio a base para a traição feita a Dantès pelos personagens Danglars, Fernand e Caderousse, e além desses cidadãos comuns, há também o representante do estado, o oportunista substituto do procurador do rei, Villefort, que atua nos bastidores da justiça e da política para a consolidação do cativeiro de Dantès. O período dos "Cem dias" de governo de Bonaparte é bem explorado nessa parte do romance, apresentando com especial destaque uma teia de acontecimentos históricos em conjunto com manobras elaboradas pelo homem da lei, Villefort, que começa a articular planos complexos para alavancar sua carreira no período do reinado de Luís XVIII, permanece com manobras no curto 
retorno do imperador Napoleão, e se mantém nas altas esferas quando este é afastado definitivamente do poder. Uma dessas estratégias para a garantia de sua estabilidade entre os círculos do poder é o seu primeiro casamento com Renée, filha do marquês de Saint-Méran.

\section{A capilaridade}

Esses personagens mais próximos ao protagonista representarão o que Antonio Candido nomeia de "senso de capilaridade" dentro da estrutura narrativa, senso este proporcionado pelo Romantismo, que, por sua diversidade temática e estética, possibilitou aos escritores a caracterização de diversas camadas sociais em suas obras. A forma do romance conecta o que o crítico nomeia como camadas superiores e inferiores, suprimindo entre elas a distinção entre o bem e o mal, e criando dessa maneira, portanto, um ambiente mais do que propício para a vingança. Dantès convive com piratas, bandoleiros, assassinos, falsificadores e toda uma gama de foras da lei, mas a narrativa também revela o trânsito pela criminalidade e pela corrupção dos altos poderes, alicerçados pelo seu status financeiro.

Ao transformar-se em um homem de grandes recursos, Dantès tem contato com autoridades religiosas e políticas e fácil acesso a sociedades de créditos e bancos poderosos, assim como às esferas sociais consideradas inferiores. Essa mobilidade na narrativa expõe várias faces da degradação humana, seja nas brigas de punhal entre bandidos como Luigi Vampa, ou diante das manobras do barão Danglars no centro oficial do capital financeiro. Em muitos momentos, o desenrolar da história parte de um microcosmo. Por exemplo: com relação ao comportamento dos bandoleiros italianos, Cucumello e Carlini, repleto de violência e crueldade, que é ambientado em locais rudes e desprovidos de conforto. Em oposição, na ilustração de um outro mundo, surge a Sra. de Villefort, esposa do temido procurador, presença de destaque na alta sociedade parisiense e representante da mais distinta educação. Contudo, é uma criminosa dissimulada, que mata por envenenamento a mãe da primeira esposa do procurador, o empregado Barrois, e ainda tenta dar o mesmo destino ao sogro Noirtier e à enteada, Valentine. Dessa maneira, no enredo de $O$ conde de Monte Cristo, não existem regulamentos e padrões morais distintivos - prova de mais um aspecto que reforça o conjunto de traços psicológicos alimentados por sua matriz romântica.

\section{A mobilidade e a sagacidade}

Uma outra nuance a ser comentada é que desde o princípio da narrativa Dantès vive em condição de mobilidade, pois começa como um navegante, depois se torna um prisioneiro, após a fuga é um contrabandista, e mesmo quando consegue a estabilidade financeira, ao se tornar conde, continua sob uma gama de disfarces e peripécias, provocando uma série de reviravoltas e histórias paralelas, mas sempre coerentes e interligadas à ação principal: a realização da vingança contra Caderousse, Danglars, Fernand e Villefort. Essa obsessão do personagem é o que Candido analisa como a quitessência do individualismo, e este é, segundo seu pensamento, o eixo da conduta burguesa, postura essa tão próxima à forma literária do romance, que proporciona uma narrativa estruturada em uma série de acontecimentos e fatos que já haviam se iniciado com os folhetins de revistas e jornais. Para ele, o tema da vingança, embora tão velho na literatura, é fonte para um frutífero universo de composições, e o aspecto das viagens, muito frequente nessa narrativa de Dumas, vai exercer, dentro de sua perspectiva romântica, uma função semelhante às que são encontradas nos romances picarescos ou de tradição picaresca.

Para Edmond Dantès, essas viagens, antes realizadas com a liberdade do navegante que era, agora serão sonhadas na cela da prisão em If, quando o abade Faria se torna seu mestre. Esse homem de grande sabedoria, além de ajudá-lo a desvendar o que havia ocorrido para que fosse preso injustamente, além dos seus ensinamentos sobre filosofia, história, geografia, matemática e 
outras ciências, também proporciona ao jovem marinheiro o conhecimento de países e culturas diversas, o aprendizado de idiomas e, finalmente, ameniza o seu sofrimento com a esperança da fuga e da busca por justiça. Para que isso aconteça, um longo caminho terá de ser percorrido pelo herói, e nada mais apropriado do que a forma romanesca. Essa história será contada com a presença de personagens reais e fictícios, com referências a obras da literatura, com a presença de lendas e de fatos históricos, além de outras formas de representação. Como diz Marthe Robert em Romances das origens, origens do romance:

Com essa liberdade do conquistador cuja única lei é a expansão indefinida, o romance, que aboliu de uma vez por todas as antigas castas literárias - as do gênero clássico - , apropria-se de todas as formas de expressão, explorando em benefício próprio todos os procedimentos sem nem sequer ser solicitado a justificar o seu emprego [...]

Gênero revolucionário e burguês, democrático por opção e animado por um espírito totalitário que o leva a romper obstáculos e fronteiras, o romance é livre, livre até o arbitrário e até o último grau da anarquia [...]

Da literatura, o romance faz rigorosamente o que quer: nada o impede de utilizar para os seus próprios fins a descrição, a narração, o drama, o ensaio, o comentário, o monólogo, o discurso; nem de ser a seu bel-prazer, sucessiva ou simultaneamente, fábula, história, apólogo, idílio, crônica, conto, epopeia; nenhuma prescrição, nenhuma proibição vem limitá-lo na escolha de um tema, um cenário, um tempo, um espaço [...] (ROBERT, 2007, p. 13).

Edmond não é retratado como um herói ingênuo, e isso reforça a composição do personagem com relação aos valores estimados por ele e que se apresentam desde o começo da narrativa: a discrição, o senso de justiça e solidariedade com os companheiros de trabalho, os cuidados com o pai, o compromisso com Mercedes e um comportamento que não se mostra subserviente ao patrão, o armador sr. Morrel. Antes de ser envolvido nas acusações de vínculo com o grande exilado, durante a sua última viagem, quando faz a parada na ilha de Elba para entregar a carta do capitão Leclère ao grão-marechal Bertrand, acaba encontrando por acaso com Napoleão Bonaparte, mas não comenta isso com ninguém no navio, e muito menos que um tio do armador havia sido citado na breve conversa que teve com o imperador. Também percebe a má índole de Danglars, mas não o prejudica quando o sr. Morrel faz perguntas sobre ele. Ao chegar a Marselha e encontrar o pai passando necessidades, devido a Caderousse ter cobrado um empréstimo ao velho homem, nota a mesquinhez e ganância do vizinho. E com relação a Fernand, não perde a oportunidade de falar abertamente sobre a rispidez deste com relação a sua chegada à casa de Mercedes. Essas situações reforçam uma personalidade que já manifestava atenção diante do comportamento das outras pessoas, e essa será uma das principais características do futuro conde vingador: observar minuciosamente o ser humano.

Como enfatiza Candido, $O$ conde de Monte Cristo foi escrito em colaboração com o historiador Auguste Maquet, e há nessa relação um destaque especial para a presença de três cidades: Marselha, Roma e Paris. Esta última, na opinião do crítico, é a parte mais problemática do romance, devido à prolixidade e à redundância dos diálogos. Embora não toque nesse aspecto do processo de elaboração da obra no seu ensaio, talvez as características problemáticas se expliquem pelo fato de na época Dumas ser pago pelos jornais em função do número de linhas redigidas. Como bem observa Rodrigo Lacerda no seu texto "A grande ficção de bom gosto" (LACERDA, 2008, p. 8), a origem da obra é folhetinesca, e devido a isso acaba apresentando as contradições naturais provocadas pelo longo período de escrita, entre agosto de 1844 a janeiro de 1846.

A contribuição de August Maquet na feitura do romance é comentada pelo próprio Dumas em seu texto "O estado civil de Monte Cristo", ao dizer que nos momentos iniciais de 
escrita, o enredo não estava totalmente pensado. Foi Maquet que chamou atenção para que fossem desdobrados aspectos primordiais para a narrativa, como o amor de Dantès por Mercedes, a traição de Danglars e Fernand e o período de convivência na prisão com o abade Faria. É uma pena que mais adiante os dois rompessem a amizade e a parceria intelectual, pois Maquet aciona Dumas na justiça em busca de direitos coautorais e acaba perdendo a causa em 1858.

\section{Um ícone}

Escrito há mais de cento e cinquenta anos, $O$ conde de Monte Cristo continua sendo uma das referências do movimento romântico, e a figura de Edmond Dantès se tornou um ícone no imaginário de seus leitores. Além da trajetória desse indivíduo, temos na narrativa referências a desdobramentos de um evento que marcou a história da humanidade, a Revolução Francesa, cujos desdobramentos figuram no romance de modo explícito com a presença de Napoleão Bonaparte, tão marcante para romancistas como Stendhal e Tostói, assim como permeiam a obra os elementos daquele contexto: a ênfase no individualismo, no capital e na propriedade, os bastidores da política e da imprensa, o lado obscuro do judiciário, aspectos sempre tão pertinentes às estruturas de convivência social no período.

Em 2012 o jornalista norte-americano Tom Reiss publica $O$ conde negro, uma biografia que trata da história do pai de Alexandre Dumas, um importante general do exército francês no período de consolidação da Revolução Francesa, e que contribuiu de maneira significativa para a ascensão de Napoleão Bonaparte em sua campanha no Egito. A vida desse homem, que teve carreira militar brilhante, foi feito prisioneiro na Itália e passou por muitos sofrimentos até sua libertação, contribuiu, segundo Reiss, para a elaboração de Edmond Dantès. Mas, ao contrário do jovem marinheiro, o pai de Dumas não conheceu um benfeitor à altura do abade Faria e nem possuía recursos financeiros para conseguir reconhecimento por seus méritos, seja pelos métodos institucionais, seja por meios ilícitos. Ele morreu com dificuldades financeiras e esquecido por Napoleão e outras autoridades. E o grande escritor, que o seu filho viria a se tornar, só pôde fazer justiça ao pai atribuindo muito de suas características a histórias emblemáticas como $O$ conde de Monte Cristo e Os três mosqueteiros. É pelo poder da palavra, transfigurada em ficção, mas que não a impede de ser tão verdadeira quanto os fatos, que o romancista vinga a memória do general injustiçado e a faz reverberar no imaginário de seus leitores. Como observa Reiss:

Da traição mais profunda, Alexandre Dumas excogitaria mundos imaginários que ressuscitaram os sonhos de seu pai e a fantástica era de glória, honra, idealismo e emancipação que ele defendeu. (REISS, 2015, p. 375).

\section{Individualismo burguês versus desejo de justiça}

Em continuidade às observações de Candido, importa ressaltar seu comentário sobre a influência visível de Byron na composição de Dantès e as menções sobre essa característica na própria obra, quando Franz d'Épinay associa-o diretamente aos personagens do romântico inglês, como Manfredo, Lara e Werner. Vale ressaltar que o crítico não analisa em detalhes outros personagens da narrativa - ele se detém no herói, e faz uma leitura fundamentada na ideia de vingança como uma postura burguesa e egocêntrica, pautada em interesses pessoais e distante de uma preocupação com o coletivo. Mas apesar de haver esse traço individualista muito forte, não há como o leitor permanecer indiferente à revolta do personagem e à sua busca por justiça, mesmo ela estando envolta em comportamentos arbitrários.

$\mathrm{O}$ individualismo da personagem e o destaque de suas ações não podem ser desvinculados das propriedades de um modo de contar histórias inovador e propenso a causar 
grande impacto diante do público leitor e ouvinte, e que está muito ligado à experiência humana. Como destaca Ian Watt:

O romance é a forma literária que reflete mais plenamente essa reorientação individualista e renovadora. As formas literárias anteriores refletiam a tendência geral de suas culturas a conformarem-se à prática tradicional do principal teste da verdade: os enredos da epopeia clássica e renascentista, por exemplo, baseavam-se na História ou na fábula e avaliavam-se os méritos do tratamento dado pelo autor segundo uma concepção de decoro derivada dos modelos aceitos no gênero. O primeiro grande desafio a esse tradicionalismo partiu do romance, cujo critério fundamental era a fidelidade à experiência individual - a qual é sempre única e, portanto, nova. Assim, o romance é o veículo literário lógico de uma cultura que, nos últimos séculos, conferiu um valor sem precedentes à originalidade, à novidade. (WATT, 1990, p. 15).

Vale salientar que a couraça da qual a personagem se traveste é rompida em alguns momentos, por exemplo: ao retornar a Marselha, muitos anos depois de seu cativeiro em If, sob o disfarce de emissário do escritório Thomson \& French, emociona-se ao rever o senhor Morrel e a família, assim como os antigos companheiros do Pharaon, que não o reconhecem. Também ajuda, através de um intermediário, um jovem casal que agora ocupa a sua antiga casa. Mais adiante, já como o conde de Monte Cristo, quando encontra Mercedes, ao chegar a Paris, tem que dissimular o abalo que isso lhe causa, e ao visitar os filhos do senhor Morrel e rever a bolsa de seda vermelha, que é tão emblemática na história dele e da família dos amigos, quase não consegue se manter sob seu disfarce.

Por outro lado, os momentos de frieza e autoritarismo do personagem durante boa parte da narrativa são muito presentes: basta lembrar o início do plano de vingança, quando ainda está em Roma, como a personagem reage às cenas de execução na Praça del Popolo e seu comportamento durante a mazzolata ${ }^{4}$; o massacre psicológico que faz a Bertuccio para confirmar o crime de Villefort contra o próprio filho, na casa de Auteuil; a maneira como trata os empregados Ali e Baptistin. Mas existe uma alternância de comportamento, com pequenos desequilíbrios emocionais, quando, por exemplo, tem contato com os Morrel ou quando fica a sós com Mercedes, embora esses sentimentos sejam logo suplantados pela encarniçada obediência ao programa de concretização da vingança.

Para alcançar essa finalidade, Dantès também é revestido de uma caracterização oriental, e é através desses traços tão distantes da cultura europeia que vai impressionar a todos, com a exposição ostensiva de decorações luxuosas nas propriedades adquiridas, pelos seus trajes e

\footnotetext{
${ }^{4}$ No capítulo 14, Parte II, Dumas apresenta um dos mais cruéis processos de execução que a pena de morte já suscitou. Como o próprio autor deixa sugerido por meio das falas dos personagens e das observações de Dantès, trata-se do processo de execução utilizado pelo Estado Pontifício entre os séculos XVIII e XIX. O nome italiano remete a "clava", "maça", "porrete". Enquanto se prepara em Roma para assistir a uma dessas sessões, Dantès discorre cinicamente alusivo: "Isso os priva de uma guilhotinada, mas resta-lhes a mazzolata, um suplício bastante curioso quando visto pela primeira vez, e até mesmo na segunda; enquanto o outro, que devem conhecer aliás, é muito simples e monótono: não acontece nada de inesperado. [...] - Por favor - acrescentou o conde num tom desdenhoso -, não me venham falar dos europeus no que se refere a suplícios, eles não entendem nada disso, achando-se na verdade na infância, ou melhor, na velhice da crueldade. - Na verdade, senhor conde - respondeu Franz -, parece que o senhor fez um estudo comparado dos suplícios nos diferentes povos do mundo. - São poucos os que não vi - replicou friamente o conde. - E sentiu prazer ao assistir a esses horríveis espetáculos? - Minha primeira reação foi de repulsa, a segunda, de indiferença, a terceira, de curiosidade. - Curiosidade! Palavra terrível, não acha? - Por quê? Na vida não há senão uma preocupação grave: a morte. Pois bem! Não é curioso estudar as diferentes maneiras pelas quais a alma pode sair do corpo, e como, dependendo das características, dos temperamentos e até mesmo dos costumes do país, os indivíduos suportam essa suprema passagem do ser ao nada? Quanto a mim, defendo um ponto de vista: quanto mais se viu morrer, mais se torna fácil morrer. Logo, do meu ponto de vista, a morte talvez seja um suplício, mas não uma expiação.” (DUMAS, 2008, p. 428-429).
} 
maneiras de servir a comida, assim como no uso do haxixe, que, ainda na caverna secreta da ilha de Monte Cristo, quando se apresentava como "Simbad", causara forte impressão a Franz d'Épinay. Para alcançar seus objetivos e evitar qualquer suspeita sobre seu passado, é preciso esquecer suas origens e encenar uma existência na verdade indiferente aos valores preconizados pela alta sociedade parisiense, da qual agora faz parte, utilizando para isso inúmeros subterfúgios.

Dentre as muitas características do conde, uma chama a atenção: sua ausência de apetite, tanto nas suntuosas refeições que oferece aos seus convidados, quanto na recusa a se alimentar quando frequenta a casa dos inimigos. Quem percebe esse estranho comportamento é Mercedes, que pede ao filho Albert para ajudá-la a fazer o conde comer algo, o que não ocorre. Ao conseguir ficar a sós com Monte Cristo, ela continua insistindo, dizendo que há um costume árabe que une para sempre os amigos que dividiram o pão e o sal sob o mesmo teto, mas o conde responde secamente que na França não existe mais amizades eternas, apenas a divisão do pão e do sal. É como se houvesse uma penitência, uma culpa pela morte por inanição de seu querido pai, assim como pela lembrança da fome durante dos anos de prisão que sofreu no Castelo de If. Essas duras lembranças, junto ao objetivo de castigar os quatro traidores, impulsionam sua desforra em pequenos detalhes, como esse de não comer junto aos seus inimigos.

Todos esses fatores correspondem à visão de Antonio Candido sobre uma das características basilares do romantismo: a estética baseada nos movimentos, no deslocar incessante de planos, que revelam o desequilíbrio genuíno do ideal romântico. Para o crítico, Dantès se caracteriza pela contradição, pois ao mesmo tempo em que tem a capacidade de se adaptar a esse mundo novo, conserva aspectos que reproduzem uma conduta arrivista como a compra das consciências, a ênfase egocêntrica na sua fortuna, no seu saber, nas festas e nos banquetes luxuosos.

Mas se observarmos o comportamento de Villefort, o único dos traidores com uma origem nobre, o seu modo de agir é muito mais violento e acintoso do que o de Dantès, mais ainda por ser um representante da justiça, que vai ascendendo na carreira através de manobras e ardis respaldados por contatos e relações políticas, e ainda é capaz de enterrar vivo o filho recémnascido concebido fora do casamento. No início da estória, o cinismo ao atender em seu gabinete em Marselha o senhor Morrel, quando este tentava salvar o jovem Dantès da acusação de agente bonapartista, caracteriza enfaticamente a sua ampla conduta criminosa, favorecida pela burocracia e desorganização institucional. Esse mandatário da lei revela desde então ser moldado pela "sofisticada corrupção que resultava no perfeito homem civilizado" (DUMAS, 2008, p. 1297).

Essa também é uma das questões relevantes da obra de Dumas, pois através das figuras de Villefort, Danglars e Fernand, ele expõe a corrupção e os desmandos na esfera jurídica, financeira e militar dos altos poderes da sociedade francesa. Pensar na figura de Dantès como alguém que penetra nesses meandros, por meios não lícitos, também nos faz entender que a parte nobre dessa sociedade não pode ser desvinculada dos mesmos processos ilegais para garantir os seus privilégios. Dantès, sob o disfarce que o título lhe proporciona, mascarando sua origem humilde, é mais uma peça que se encaixa nessa engrenagem sustentada por uma legitimidade de tradição, mas uma tradição tão grosseira quanto a falta de tato do personagem, apontada por Antonio Candido ${ }^{5}$, ao falar sobre a sua fortuna de novo-rico.

Ao visitar o agora barão e banqueiro Danglars, com o objetivo de solicitar acesso a um crédito ilimitado, Dantès é recebido inicialmente com desprezo.

\footnotetext{
5 A referência que Antonio Candido faz às grosserias do novo-rico Dantès acaba por sugerir uma diferença de nível com os ricos tradicionais. Em outro momento, a avaliação do crítico é mais contundente: no ensaio "De cortiço a cortiço", Candido caracteriza os ricos em conjunto ao tratar de um dito pretensamente espirituoso, corrente no Rio de Janeiro do século XIX, mas na verdade preconceituoso e racista: "Sórdido jogo, expresso neste e outros mots d'esprit, que formam uma espécie de gíria ideológica de classe, com toda a tradicional grosseria da gente fina". (CANDIDO, 1998, p. 133).
} 
- É ao senhor de Monte Cristo que tenho a honra de falar?

- E eu - respondeu o conde - ao senhor barão Danglars, cavaleiro da Legião de Honra, membro da Câmara de deputados?

Monte Cristo repetia todos os títulos que vira no cartão do barão.

Danglars sentiu a estocada e mordeu os lábios.

- Desculpe-me, cavalheiro - disse ele - , por não ter me referido de saída ao título com o qual o senhor me foi anunciado; porém, como sabe, vivemos sob um governo popular e sou um representante dos interesses do povo.

- Ou seja - espicaçou Monte Cristo - , ao mesmo tempo em que preservou o hábito de ser chamado de barão, perdeu o de chamar os outros de conde.

- Ah, tampouco faço questão do meu, senhor - respondeu displicentemente Danglars.

- Eles me nomearam barão, e fizeram-me cavaleiro da Legião de Honra por alguns serviços prestados, mas...

- Mas o senhor abdicou de seus títulos, como fizeram outrora os senhores de Montmorency e de La Fayette? É um belo exemplo a ser seguido, senhor.

- Não completamente, entretanto - disse Danglars, embaraçado, - Para os criados, o senhor entende...

- Sim, para o seu pessoal, o senhor é fidalgo; para os jornalistas, senhor; e para os eleitores, cidadão. São nuances que combinam bem com o governo constitucional. Compreendo perfeitamente. (DUMAS, 2008, p. 585-586).

Danglars fica desnorteado com a postura do conde, que vai continuar o diálogo com uma abordagem de enfrentamento, sustentada pelo poder econômico e prestígio que detém. E quando o especulador vê as cartas de crédito ilimitado que Monte Cristo já possui de outros bancos europeus, o eleva rapidamente à categoria de homem confiável.

- Com o seu bom gosto e suas intenções, cavalheiro - continuou Danglars - , o senhor vai espalhar um luxo pela capital que irá nos esmagar a todos, pobres e singelos milionários. (DUMAS, 2008, p. 589).

Seguindo o seu plano de vingança, após preparar um ardil com a assessoria de seu escravo Ali, Monte Cristo salva a esposa e o filho de Villefort, e devido a isso recebe em sua casa pela primeira vez o implacável homem da justiça, que agradece formalmente os préstimos, como se estivesse cumprindo uma obrigação protocolar, mantendo a pose rígida e inflexível, que o fazia ser apontado pelos bajuladores como a "estátua viva da lei". Em um dado momento, no decorrer de seu diálogo com o conde, diz com extrema indelicadeza:

- Pois bem! Palavra de honra! Se, como o senhor, eu nada tivesse para fazer, procuraria um passatempo menos triste.

Grosseria que ao conde não passará despercebida, e à qual revida:

- É verdade - devolveu Monte Cristo -, o homem é uma feia lagarta para quem o estuda ao microscópio solar. Mas, como acaba de dizer, não tenho nada para fazer. Vejamos, será que por acaso tem alguma coisa para fazer, cavalheiro? Ou, falando mais claramente, julga que o que faz merece ser chamado de alguma coisa? (DUMAS, 2008, p. 605).

\section{Narrativas, peripécias e redenção}

Após um jantar na casa que o conde havia comprado em Auteuil, e que é o ambiente crucial para a realização da vingança de Dantès, Villefort começa a desconfiar de Monte Cristo, e manda um investigador de polícia procurar informações justamente com o "abade Busoni", quando Dantès mascarado nesse papel informa de maneira muito convicente as origens da 
família do conde, acrescentando ainda que o nome verdadeiro deste é Zaccone. Ocorre assim um dos momentos mais engenhosos do romance, pois o policial é não menos que o sr. de Boville, o mesmo que inspecionou a prisão de If quando o jovem marinheiro estava preso, tendo sido, além de tudo, por meio dele que, sob o disfarce de representante da casa Thomson \& French, Dantès tivera acesso aos documentos que revelaram os verdadeiros motivos de sua prisão. Além do "abade", o policial também escuta outra história mirabolante a respeito de Zaccone, desta vez narrada pelo "lorde Wilmore", que Dantès, com requintes, encena ser um inimigo mortal do conde maltês. Após ouvir os dois relatos, o policial acredita que todas as informações são verdadeiras e garante a tranquilidade do cismado sr. Villefort.

Desse modo, o herói acaba se tornando, depois da fuga de If, um grande contador de histórias. Além da riqueza, do poder, dos contatos legítimos e ilícitos, também engenha sua vingança pelo poder de narrar e de se metamorfosear. Esses artifícios engenhosos surgem em muitas circunstâncias, ora salvando o protagonista de ser desmascarado, ora reforçando os seus planos, como no surgimento do "pai" e "filho" Cavalcanti, essenciais para o aniquilamento profissional e moral do procurador do rei. A perspectiva das histórias dentro da história principal converge nesse momento para a atuação de Dantès, pois é ele que conduz o fio da meada para enganar o seu algoz burocrata da justiça, apenas pelo poder da palavra, da fabulação. Dantès neutraliza temporariamente o adversário pela combinação habilidosa da linguagem, no mesmo padrão utilizado para o mal por Villefort, tanto ao prejudicar o jovem marinheiro nos momentos iniciais do romance, como, posteriormente, para ser "justo" com os homens que cairiam em suas mãos como representante da lei.

Talvez seja justamente essa postura, muitas vezes violenta e inexplicável à primeira vista, o grande mote da obra. Como também aponta Candido: por qual motivo, por exemplo, o conde demora tanto tempo para revelar a Maximilien Morrel que Valentine Villefort está viva? Seria uma espécie de provação, embora pretensiosa, para causar sofrimento a este em virtude de sua situação amorosa no passado com relação à Mercedes? Mas vale lembrar que Monte Cristo, quando escuta o jovem dizer que ama Valentine, demonstra claramente sua revolta e insatisfação, justamente pelo fato de ela ser filha de um de seus inimigos. É um dos poucos episódios em que perde o equilíbrio diante de uma situação inesperada e demonstra uma série de sentimentos conflitantes, mas que irão motivá-lo a salvar a jovem de morrer envenenada por sua madrasta, e que o levarão, ao final da narrativa, às benignas artimanhas para que a união dos dois jovens se efetive.

As várias personalidades de Dantés, de alguma maneira, oferecem uma diversidade de comportamentos e atitudes consolidantes de um estilo de narração que não obedece mais a esquemas delimitados quanto à conduta de seus personagens. $\mathrm{O}$ inexplicável também acontece, e como enfatiza Marthe Robert:

Diferentemente do gênero tradicional, cuja regularidade é de tal ordem que é não apenas submetido a prescrições e proscrições, como feito por elas, o romance não tem regras nem freio, sendo aberto a todos os possíveis, de certa forma indefinido de todos os lados. (ROBERT, 2007, p. 14).

$\mathrm{Na}$ sua condição poderosa de conde e milionário, Dantès terá acesso a informações privilegiadas, contatos em todas as camadas da sociedade e vai concretizar a sua vingança com relação aos quatro homens responsáveis por sua prisão. Caderousse será assassinado devido à cobiça infinita pelo dinheiro, Fernand Morcef comete suicídio, Villefort enlouquece - talvez seja a punição mais emblemática: a ausência de razão em um indivíduo antes tão meticuloso - e Danglars acaba na miséria, perdendo toda a fortuna acumulada durante anos de especulação. As cenas em que Dantès se revela a cada um deles são simbólicas com relação ao caráter dramático 
que reveste a forma romanesca, pois nelas estão presentes a expectativa, a tensão, o conflito, a divulgação do segredo e o desfecho trágico para os malfeitores.

Mas como observa Antonio Candido, isso não é o bastante para a dinâmica do enredo, pois o arrependimento do personagem e a desistência de atuar como a personificação da Providência divina também vão reforçar as características românticas da narrativa. $O$ ímpeto demoníaco de Dantès é sufocado em nome da redenção e do surgimento de um novo amor, que, na percepção um tanto dura do crítico, corresponde a um primeiro impulso de senilidade. A vingança não foi suficiente para a conclusão da história. Após estar perto de alcançar o seu objetivo, pois nessa altura da narrativa ainda falta Danglars ser castigado, o homem maduro e sofrido retorna a Marselha e vai visitar o Castelo de If, seu inferno na terra por quatorze anos. A masmorra está abandonada e não é mais utilizada como prisão, mas agora é visitada como uma espécie de atração turística dos horrores.

\section{CONCLUSÃO}

Sendo guiado pelo zelador, Dantès pergunta se existe alguma história sobre o Castelo sem ser sobre o cativeiro do ilustre Mirabeau, e escutará assustado a sua própria história sendo contada por outro homem: os anos de prisão, o contato com o abade pelo túnel entre as celas 34 e 27, a fuga dentro da mortalha, o lançamento ao mar com a bola de ferro presa aos pés, e a descrição dos objetos encontrados feitos por ele, "o homem perigosíssimo", e pelo abade louco. Irá rever a alcova na qual tantas vezes se desesperou e nela enxerga o que escreveu enquanto era prisioneiro: "MEU DEUS, PRESERVAI A MINHA MEMÓRIA! Esse é um dos momentos mais intensos da narrativa, tão estruturada na força do relato, da palavra e da memória, pois Dantès recorda que nem pedia mais a liberdade, pedia a memória, pois tinha medo de enlouquecer e esquecer.

Após a visita, Dantés gratifica muito bem o zelador, que, agradecido e surpreso com as moedas de ouro, retribui com a última coisa que guarda, pertencente aos prisioneiros: um manuscrito escrito em tiras de pano, feito pelo abade Faria. E nele está dito:

Arrancarás os dentes do dragão e pisotearás os leões, disse o Senhor. (DUMAS, 2008, p. 1322).

Não deixa de ser muito significativo que, nos instantes finais da história, a presença da memória seja tão evidenciada por Dumas. Através do homem que o guia pela antiga prisão, Dantès fica sabendo que está imortalizado pela narração dos contadores de história da região, que encenam para os ouvintes diante das lareiras a dura trajetória do "prisioneiro 34". Desse modo, o personagem, mais uma vez, se torna outro personagem no enredo, não mais por vontade própria e por razões da vingança, mas pelo imaginário coletivo e admiração do povo, que o vê como um mistério impossível de ser decifrado. Sendo assim, a história do jovem marinheiro, dentro desse plano de ficção, não tem fim, continuará sendo narrada por outros sujeitos, para que a vingança se torne justiça.

\section{REFERÊNCIAS BIBLIOGRÁFICAS}

CANDIDO, Antonio. Da vingança. In: Tese e antítese. São Paulo: Cia Editora Nacional, 1971.

De cortiço a cortiço. In: . O discurso e a cidade. São Paulo: Duas Cidades, 1993. p.

\section{3-152.}


DUMAS, Alexandre. O conde de Monte Cristo. Edição definitiva, anotada e ilustrada. Tradução, apresentação e notas de André Telles e Rodrigo Lacerda. Rio de Janeiro: Jorge Zahar, 2008. 2v.

LACERDA, Rodrigo. Apresentação. A grande ficção de bom gosto. In: DUMAS, Alexandre. O conde de Monte Cristo. Edição definitiva, anotada e ilustrada. Tradução, apresentação e notas de André Telles e Rodrigo Lacerda. Rio de Janeiro: Jorge Zahar, 2008. 2v.; p. 7-15.

REISS, Tom. O conde negro. Glória, revolução, traição e o verdadeiro Conde de Monte Cristo. Tradução de Cássio de Arantes Leite. Rio de Janeiro: Objetiva, 2015.

ROBERT, Marthe. Romance das origens, origens do romance. Tradução de André Telles. São Paulo: Cosac Naify, 2007.

WATT, Ian. $A$ ascensão do romance. Estudos sobre Defoe, Richardson e Fielding. Tradução de Hildegard Feist. São Paulo: Companhia das Letras, 1990. 